Canada's nineteenth century penitentiary system was a vast social experiment, characterized by extreme imbalances in power relations. In such a milieu, McCoy concludes (267), the experiences of inmates involved a great deal of punishment, but precious little justice.

Patrick J. Connor

York University

\title{
Paul Josephson, Nicolai Dronin, Ruben Mnatsakanian, Aleh Cherp, Dmitry Efremenko, and Vladislav Larin, An Environmental History of Russia (New York: Cambridge University Press, 2013). 347 pp. \$31.95 Paperback.
}

An Environmental History of Russia offers a survey of Russian/Soviet engagement with the environment from the late Tsarist to the late Soviet period. It is divided into five chapters exploring chronologically the Soviet approach to the environment during the political periods of Stalinism, the Khrushchev Reforms, Developed Socialism, and Gorbachev's Reforms. The conclusion offers insight into how post-Soviet states, particularly Russia, have dealt with the legacy of Soviet environmental policies. The book shows the importance of thinking comparatively about environmental history and placing the Soviet case into a broader story of how modern states have interacted with the environment and constructed the idea of "nature"(6). Even with its centrally-planned economy and the significant role of state actors in decision-making, the Soviet Union shared with Western democracies an innate belief in the state's "ability to improve on nature..."(12). By emphasizing an understanding of nature "as a site of human and other interactions in all ecosystems," including urban as well as rural spaces, this book provides a nuanced picture of how changes to the environment shaped and were shaped by human activities.

The resource rich territory of the Soviet Union offered considerable opportunity for the country to develop economically. As the authors describe, fertile farmland, dense forests, great waterways, and an abundance of raw materials provided a solid foundation for Soviet industrialisation; yet, the pace of industrialisation and the mismanagement of these resources led to tremendous waste and damage to the environment, in addition to the great cost in human lives. Forced labour from the Gulag camps during the Stalinist years made possible the pace and scale of this development, especially in Russia's remote northern regions. While this reliance on forced labour ended with Stalin's death, subsequent Soviet leaders "continued to embrace inefficient and highly polluting largescale projects as the foundation of the economy"(37). The state initiated largescale projects to demonstrate the superiority of socialism and pushed the economy forward in its competition with the West. These "hero projects," such as the Kara-Kum Canal, while ambitious feats of engineering, were undertaken without 
much consideration of their ecological impact.

The context of the Cold War looms large in this story, shaping the Soviet Union's understanding of and policies toward the environment. On the one hand, the military competition of the Cold War pushed the Soviet leaders into undertaking "policies that favored big industry, big agriculture, and big forestry," thereby contributing greatly to environmental degradation (180). Yet this competition also inspired Soviet leaders to use environmental laws as another way "to demonstrate the superiority of the Soviet system"(186). For instance, under Leonid Brezhnev, Soviet environmental policy flourished as the state passed new laws and decrees related to environmental protection in response to international awareness and activism. Although this did not translate into concrete action, in part due to lax enforcement without a national environmental body, it created new space in the Soviet Union to discuss and research these issues (251).

The book also explores the role of civil society, particularly the scientific community in voicing support for conserving and preserving the environment. Even under Stalin, albeit to a much lesser extent than in subsequent periods, groups continued to study environmental issues and push for some protection of the environment, especially in the form of nature reserves (110). Even though more debate and activism became possible under the subsequent leadership of Nikita Khrushchev and Leonid Brezhnev, it was not until the late 1980s, as Mikhail Gorbachev's reforms took root that an environmental movement among the population strengthened (275). In some republics, this interest had a nationalist quality, as independence movements identified environmental degradation with policies originating out of the Soviet centre (279).

As a survey, the strength of this book is in the breadth of issues it covers, offering a broad sweep of many environmental themes related to resource extraction, agricultural development, urbanisation, and energy production. By offering an overview of Soviet policies and actions in a variety of ecosystems, including urban and rural spaces, and the economic and political ideas that inspired these interactions, this book makes an important contribution to the growing discussion of Russian environmental history and identifies topics in need of future research.

Aileen Friesen

University of Illinois at Urbana-Champaign 